\title{
Evaluation Patch of Rhizoma Extract Kencur (Kaempferia galanga L.) as Anti-Inflammatory with Enhancer
}

\author{
Hesti Riasari*, Revika Rachmaniar, Sri Wahyuni \\ Department of Pharmaceutical Biology, Indonesia School of Pharmacy, Bandung - Indonesia \\ Submitted 9 October 2018; Revised 8 January 2019; Accepted 16 January 2019; Published 27 June 2019 \\ *Corresponding author: hmm_riasari@yahoo.com

\begin{abstract}
Kencur (Kaempferia galanga L.) is a family of Zingiberaceae. Several studies have shown that kencur can help reduce inflammation because kencur is known to contain anti-inflammatory compounds, namely marker compounds from flavonoids, kaempferol. For the development of pharmaceutical preparations, research on anti-inflammatory plasters containing $96 \%$ ethanol extract, $n$-hexane extract, ethyl acetate extract and 70\% ethanol extract from ginger rhizome with the addition of penetration enhancer (enhancer), namely propylene glycol. This anti-inflammatory plaster was tested for its activity in 5 groups of Wistar strain rat feet which had been induced 1\% carrageenan (negative control); positive control (diclofenac sodium), ethano196\% extract, n-hexane extract, ethyl acetate extract and $70 \%$ ethanol extract from kencur rhizome and compared with plaster of kencur rhizome ethanol extract without enhancer. The results showed the effect of adding enhancers 30 minutes after administration. $96 \%$ ethanol extract and ethyl acetate extract had reduced inflammation by $79.99 \%$ in rat test animals compared to plaster ethanol extract of rhizome kencur without the addition of enhancers.
\end{abstract}

Keywords: Anti-inflammatory, enhancer, Kaempferia galanga. L., patch, propylene glycol.

\section{Evaluasi Sediaan Plester dari Ekstrak Rimpang Kencur (Kaempferia galanga L.) sebagai Anti-Inflamasi dengan Penambahan Peningkat Penetrasi}

\begin{abstract}
Abstrak
Kencur (Kaempferia galanga L.) merupakan famili Zingiberaceae. Beberapa penelitian membuktikan bahwa kencur dapat membantu mengurangi peradangan karena kencur diketahui mengandung senyawa antiradang yaitu senyawa penanda dari flavonoid, kaempferol. Untuk pengembangan sediaan farmasi, dilakukan penelitian tentang plester antiinflamasi yang mengandung ekstrak etanol $96 \%$, ekstrak n-heksan, ekstrak etil asetat dan ekstrak etanol 70\% dari rimpang kencur dengan penambahan peningkat penetrasi (enhancer) yaitu propilen glikol. Plester antiinflamasi ini diiuji aktivitasnya pada 5 kelompok kaki tikus galur Wistar yang telah diinduksi karagenan 1\% (kontrol negatif); kontrol positif (natrium diklofenak), ekstrak etano196\%, ekstrak n-heksan, ekstrak etil asetat dan ekstrak etanol 70\% dari rimpang kencur dan dibandingkan dengan plester ekstrak etanol rimpang kencur tanpa enhancer. Hasil penelitian menunjukkan pengaruh penambahan enhancer pada 30 menit setelah pemberian, Ekstrak etanol $96 \%$ dan ekstrak etil asetat sudah mengurangi peradangan sebanyak $79,99 \%$ pada hewan uji tikus dibandingkan dengan plester ekstrak etanol rimpang kencur tanpa penambahan enhancer.
\end{abstract}

Kata Kunci: Anti-inflamasi, Kaempferia galanga L, plester, peningkat penetrasi, propilen glikol 


\section{Pendahuluan}

Kulit adalah bagian terluar dari tubuh sehingga merupakan organ pertama yang dapat kontak dengan berbagai rangsangan fisika atau kimia. Pemberian obat melalui kulit sering menawarkan alternatif rute pelepasan yang lebih lambat dan lebih terkontrol ke aliran darah. Mekanisme bagaimana obat berpenetrasi ke kulit dan masuk ke aliran darah bukanlah hal yang mudah karena kulit bertindak sebagai pembatas alami. Oleh karena itu, penting untuk memahami struktur kulit dan pada stratum korneum tertentu atau permukaan lebih luar sebelum mencoba menempatkan obat untuk melaluinya. Secara struktural, kulit terdiri dari dua bagian utama; bagian luar, lapisan tipis disebut epidermis dan bagian dalam lebih tebal disebut dermis. ${ }^{1}$ Ada tanda-tanda peradangan, seperti rubor (kemerahan), kalor (panas), dolor, tumor (bengkak), dan penurunan fungsi dari organ yang terkena radang. Respon peradangan dapat dikenali dari rasa sakit, kulit lebam, demam yang disebabkan karena terjadi perubahan pada pembuluh darah di area infeksi, seperti pembesaran diameter pembuluh darah disertai peningkatan aliran darah di daerah infeksi. Hal ini yang membuat kulit tampak lebam kemerahan.

Kencur (Kaempferiae galanga L.) yang termasuk suku temu-temuan (Zingiberaceae) merupakan terna kecil yang tumbuh subur di daerah dataran rendah atau pegunungan yang tanahnya gembur. ${ }^{2}$

Kandungan kimia dalam ekstrak minyak atsiri dari kencur yang telah diteliti oleh ${ }^{3}$ diantaranya yaitu 1,21-dokosadin, asam tridekaoat, pentadekan, asam propionate, beta-sitosterol dan kandungan kimia terbesar didalam kencur yaitu Etil p- metoksisinamat, juga disebutkan bahwa kandungan eukaliptol, karvon, pentadekan dan metal sinamat.<smiles>O=c1c(O)c(-c2ccc(O)cc2)oc2cc(O)cc(O)c12</smiles>

Gambar 1. Struktur kimia kaempferol
Salah satu zat kimia pada rimpang kencur bersifat antiinflamasi atau antiradang, yaitu kaempferol. Kaempferol mempunyai kemampuan menghambat proses inflamasi dengan cara menghambat ekspresi enzim cyclooxygenase-2 (COX-2).

Penelitian tentang efek anti-inflamasi ekstrak etanol rimpang kencur dengan menggunakan model in vitro mengatakan bahwa rimpang kencur terbukti memiliki efek antiinflamasi. Oleh karena itu, ekstrak kencur berpotensi untuk dijadikan plester antiinflamasi untuk membantu mempercepat proses penyembuhan inflamasi. ${ }^{4,5}$

Plester obat merupakan sediaan yang bersifat lentur mengandung satu atau lebih zat aktif. Sediaan tersebut dimaksudkan untuk digunakan pada kulit. Plester obat dirancang untuk mempertahankan zat aktif kontak langsung dengan kulit yang mungkin diabsorbsi secara perlahan, atau bertindak sebagai bahan keratolitik atau protektif. ${ }^{6}$

Peningkat penetrasi (enhancer) adalah bahan yang dapat meningkatkan permeabilitas kulit ataupun mengurangi impermeabilitas kulit. Bahan peningkat penetrasi tidak memiliki efek terapi, tetapi dapat mentransport obat dari bentuk sediaan ke dalam kulit. ${ }^{7}$ Alasan dibutuhkan penggunaan bahan peningkat penetrasi adalah adanya barier penetrasi, yaitu stratum korneum. Peningkatan penetrasi obat dapat dilakukan menggunakan peningkat penetrasi kimia maupun fisika. ${ }^{8}$

\section{Metode}

2.1. Alat

Alat yang digunakan pada penelitian ini adalah timbangan analitik (Henherr dan Sartorius), maserator, rotavapor (rotary vaporator) (IKA), labu vaporasi (IKA), vakum (IKA) dan labu penampung (IKA), oven, mortir dan stamper, cawan penguap, pinset (Meiden), batang pengaduk, spatula, pelat tetes, disposable spuit (OneMed), serta alat-alat gelas (pyrex) yang biasa digunakan dalam laboratorium.

\subsection{Bahan}

Bahan yang digunakan pada penelitian 
ini adalah rimpang kencur (Kaempferia galanga L.), pelarut untuk maserasi etanol 96\% (Brataco), n-heksan (Brataco), etil asetat (Brataco), pereaksi-pereaksi skrining, gliserin, propilen glikol, aquadest (Brataco), kasa steril (Husada), plester (Hansaplast) dan sediaan gel mengandung natrium diklofenak.

Hewan percobaan yang digunakan dalam penelitian ini adalah tikus putih jantan galur Wistar yang berumur 2,5-3 bulan dengan bobot badan 140-210 gram.

\subsection{Determinasi Tanaman}

Tumbuhan dideterminasi di bagian Herbarium Laboratorium Taksonomi, Jurusan Biologi, Fakultas Matematika dan Ilmu Pengetahuan Alam, Universitas Padjadjaran.

\subsection{Penyiapan Simplisia Rimpang Kencur} (Kaempferiae galanga L.)

Rimpang kencur (umur 10-12 bulan) diperoleh dari Perkebunan Manoko, Lembang, Jawa Barat. Rimpang kencur disortasi basah, dicuci, ditiriskan, dirajang melintang dengan ketebalan 2-5 $\mathrm{mm}$ dan dikeringkan di dalam oven dengan suhu $40-50^{\circ} \mathrm{C}$ hingga kering (kadar air $\leq 10 \%)^{9}$

\subsection{Ekstraksi}

Ekstraksi dilakukan dengan cara maserasi dari simplisia 250 gram dengan pelarut etanol 96\% $800 \mathrm{ml}$, dengan 3 kali penggantian pelarut selama 3 hari. Ekstrak cair yang telah dikumpulkan diuapkan dengan rotary vaporator pada suhu $40-50^{\circ} \mathrm{C}$. Selanjutnya dalam cawan penguap, maserat dipanaskan di atas penangas air dengan suhu tidak lebih dari $50^{\circ} \mathrm{C}$, sehingga diperoleh ekstrak kental. ${ }^{10}$

Metode ekstraksi kepolaran bertingkat dilakukan dengan cara maserasi dari simplisia 250 gram dengan pelarut n-heksan sebanyak $800 \mathrm{ml}$, dengan 3 kali penggantian pelarut selama 3 hari. Setelah itu ampas dilakukan hal yang sama dengan menggunakan pelarut etil asetat dan etanol $70 \%$.

\subsection{Skrining Fitokimia Ekstrak}

Untuk mengetahui kandungan metabolit sekunder yang terdapat dalam ekstrak rimpang kencur, maka dilakukan penapisan fitokimia steroid dan terpenoid berdasarkan metode pada ${ }^{11}$ dan metode ${ }^{12}$ untuk Flavonoid, Saponin. Pengujian untuk senyawa alkaloid, polifenol dan tanin menggunakan metode. ${ }^{13}$ Pengujian untuk senyawa kumarin, quinon menggunakan metode. ${ }^{14}$

\subsection{Pembuatan Plester Antiinflamasi}

Pada penelitian ${ }^{4}$ ekstrak etanol dijenuhkan ke dalam bantalan luka yang telah disiapkan, lalu ditambahkan etanol $96 \%$. Setelah itu, bantalan luka tersebut ditempelkan pada plester perekat (Dosis ekstrak yang diberikan adalah $18 \mathrm{mg}$ ).

Sediaan plester antiinflamasi yang dibuat terdiri dari 5 kelompok uji, yaitu kelompok kontrol negatif yang hanya diberikan gliserol dan propilen glikol. Kelompok kontrol positif diberikan gel natrium diklofenak dan propilen glikol sebagai standar. Kelompok plester ekstrak etanol 96\% diberikan senyawa ekstrak etanol dan propilen glikol. Kelompok plester ekstrak n-heksan dan propilen glikol, kelompok ekstrak etil dengan propilen glikol, kelompok ekstrak etanol $70 \%$ dengan propilen glikol, semua kelompok ditambahkan propilen glikol sebagai peningkat penetrasi Ekstrak n-heksan diteteskan ke dalam bantalan luka yang telah disiapkan, lalu ditambahkan n-heksan. Setelah itu, bantalan luka tersebut ditempelkan pada plester perekat. Dosis ekstrak yang digunakan sebanyak $18 \mathrm{mg}$. Hal yang sama dilakukan pada ekstrak etil asetat dan etanol $70 \%$.

\subsection{Uji Plester Antiinflamasi}

Pengujian antiinflamasi plester rimpang kencur yang ditambah propilen glikol dilakukan terhadap 5 kelompok hewan uji, masing-masing kelompok terdiri dari 3 ekor tikus putih galur Wistar. Kaki kiri tikus diberi tanda batas dengan spidol agar pemasukan kaki ke dalam air raksa setiap kali selalu sama. Lalu volume kaki tikus diukur sebelum (Vo) dan sesudah (Vt) diinduksi larutan karagenan $1 \%$ pada bagian telapak kakinya secara subkutan dan ditempelkan plester uji, dengan cara dimasukkan ke dalam cairan 
air raksa, lalu dicatat volume kakinya setiap 1 jam sekali hingga jam ke-5. Kemudian dicatat hasil pengamatannya dan dibuat tabel ANOVA. Kelompok hewan uji I sebagai kontrol negatif, kelompok hewan uji II sebagai kontrol positif, kelompok hewan uji III diberikan plester yang dijenuhkan ekstrak etanol rimpang kencur $18 \mathrm{mg} .{ }^{4}$

Hal yang sama dilakukan untuk sediaan plester fraksi n-heksan, fraksi etil asestat dan fraksi etanol rimpang kencur sebagai kelompok hewan uji IV, V dan VI dengan penambahan propilen glikol sebagai peningkat penetrasi.

\section{Hasil}

Determinasi tanaman yang dilakukan di bagian Herbarium Laboratorium Taksonomi, Jurusan Biologi, Fakultas Matematika dan Ilmu Pengetahuan Alam, Universitas Padjadjaran menunjukkan bahwa tanaman yang digunakan dalam penelitian adalah rimpang kencur (Kaempferiae galanga L.).

Hasil pengamatan inhibisi radang ratarata dapat dilihat pada Gambar 2.

\section{Pembahasan}

Pada proses ekstraksi digunakan metode maserasi dengan cairan penyari etanol 96\%. Maserasi dipilih pada proses ekstraksi rimpang kencur karena kandungan minyak atsiri dan flavonoid yang berkhasiat dalam kencur bersifat termolabil. Etanol 96\% dipilih karena dapat melarutkan hampir semua metabolit sekunder yang terkandung dalam simplisia. Dari 250 gram simplisia rimpang kencur yang diekstraksi dengan pelarut etanol $96 \%$, diperoleh rendemen ekstrak adalah 20,56\% yang artinya sesuai dengan persyaratan ${ }^{15}$ yaitu hasil rendemen lebih dari 8,3\%. Dalam proses ekstraksi suatu bahan tanaman, banyak faktor yang dapat mempengaruhi kandungan senyawa hasil ekstraksi diantaranya: jenis pelarut, konsentrasi pelarut, metode ekstraksi dan suhu yang digunakan untuk ekstraksi. ${ }^{16}$

Hasil yang diperoleh dari penapisan fitokimia pada semua sampel, positif mengandung flavonoid, senyawa tersebut merupakan senyawa yang memiliki aktivitas antiinflamasi. Untuk senyawa tanin, yang memberikan hasil positif pada ekstrak etanol, ekstrak bersinambung $n$-heksan dan ekstrak bersinambung etil asetat. Untuk golongan fenolat, hanya pada ekstrak etanol dan ekstrak bersinambung etil asetat saja yang menunjukkan hasil positif, karena fenolat merupakan senyawa semi polar.

Pada proses ekstraksi berdasarkan kepolaran yang bertingkat dengan cairan penyari menggunakan $n$-heksan untuk menarik senyawa-senyawa yang bersifat non polar. Dari 250 gram simplisia rimpang kencur dengan pelarut $\mathrm{n}$-heksan dengan rendemen $13,12 \%$; rendemen dengan menggunakan pelarut etil asetat yaitu sebesar 5,52\% dan rendemen etanol sebesar 5,8\%.

Berdasarkan hasil rendemen pada metode ekstraksi dengan kepolaran yang bertingkat lebih besar persentase nya dibandingkan metode ekstraksi dengan pelarut etanol 96\%. Hal ini disebabkan oleh proses penarikan metabolit sekunder yang lebih baik dan efektif karena masing masing senyawa tertarik oleh pelarut yang sesuai dengan kepolarannya sehingga total dari masing masing rendemen pada ektrsk $n$-heksan, etil asetat dan etanol $70 \%$ lebih besar.

Hasil pengamatan inhibisi radang ratarata dapat dilihat pada Gambar 2. Setelah diamati dari Gambar 2, dari keempat sampel

Tabel 1. Hasil pemeriksaan parameter mutu simplisia rimpang kencur

\begin{tabular}{lcc}
\hline \multicolumn{1}{c}{ Jenis Karakterisasi } & Kadar (\%) & \\
& Simplisia & Persyaratan \\
\hline Kadar Air & 10 & $\leq 10$ \\
Kadar Abu Total & 5,5 & $<8,7$ \\
Kadar Sari Larut Air & 17 & $>14,2$ \\
Kadar Sari Larut Etanol & 37 & $>4,2$ \\
Susut Pengeringan & 6,68 & $\leq 10$ \\
\hline
\end{tabular}




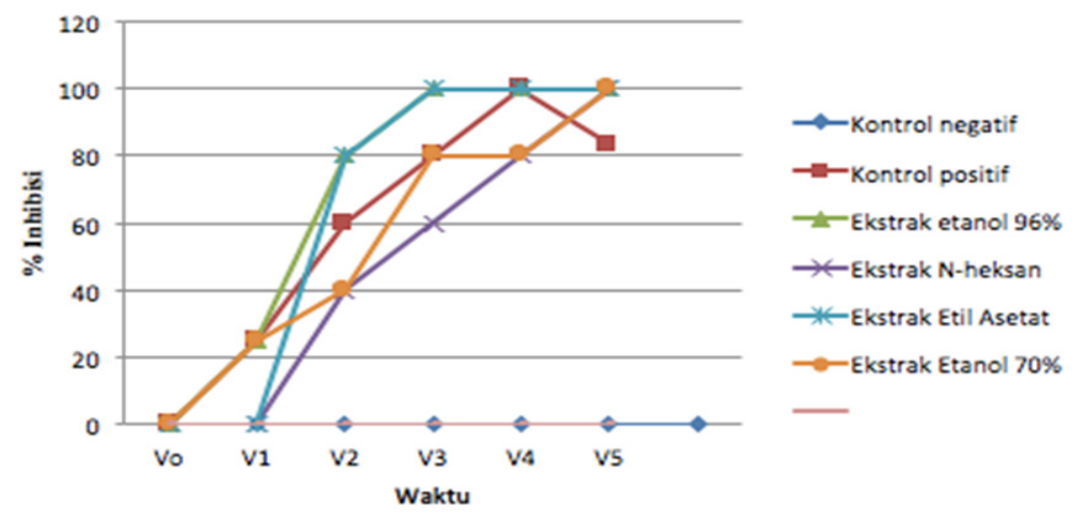

Gambar 2. Grafik inhibisi (\%) terhadap waktu pengukuran volume kaki tikus(t)

yang diberikan dengan dosis $18 \mathrm{mg}$, sampel ekstrak etanol 96\% dan ekstrak etil asetat yang diberi peningkat penetrasi sangat baik mengurangi radang dibandingkan kontrol positif (natrium diklofenak) memberikan efek antiinflamasi terbaik. Parameter volume udem berkurang setelah 30 menit pemberian persentasi sebesar $79,99 \%$ yaitu dilihat dari grafik persen inhibisinya yang semakin meningkat menit ke-60 sebesar 100\% dibandingkan kontrol positif sebesar 80,01\%.

Perbedaan dari penelitian sebelumnya, yaitu ${ }^{4}$ yang tidak menambahkan propilen glikol itu terlihat pada hasil dari perbedaan dosis. Pada plester ekstrak rimpang kencur dosis terendah dari penelitian sebelumnya, yaitu dosis $18 \mathrm{mg}$ yang tidak menambahkan propilen glikol tidak memberikan aktivitas antiinflamasi pada menit ke-30 dan baru memberikan aktivitas antiinflamasi pada menit ke-90 dengan nilai inhibisi 29,59\%.

Sediaan plester ekstrak etanol 96\% dan ekstrak etil asetat dosis $18 \mathrm{mg}$ dengan penambahan propilen glikol ini menunjukkan peningkatan efektifitas yang cukup signifikan mengurangi radang. dibandingkan dengan sediaan plester ekstrak rimpang kencur dosis $18 \mathrm{mg}$ tanpa penambahan propilen glikol karena propilen glikol merupakan senyawa yang inert dan dapat meningkatkan penetrasi senyawa sebagai antiinflamasi. Dengan demikian, dosis $18 \mathrm{mg}$ merupakan dosis yang baik dan efektif untuk dibuat sediaan plester anti-inflamasi.

Berdasarkan hasil analisis one way ANOVA pada hewan percobaan tikus jantan dengan tingkat kepercayaan 95\% didapat angka yang signifikan yaitu $\rho<0,05$ sehingga dapat disimpulkan bahwa semua sediaan plester dengan penambahan peningkat penetrasi memiliki aktivitas antiinflamasi dengan variasi waktu yang berbeda.

\section{Simpulan}

Berdasarkan penelitian yang telah dilakukan dapat disimpulkan bahwa ekstrak etanol 96\% dan ekstrak etil asetat rimpang kencur dengan penambahan propilen glikol sebagai peningkat penetrasi (enhancer) dalam dosis $18 \mathrm{mg}$ merupakan dosis yang baik dan efektif untuk mengurangi inflamasi.

\section{Ucapan Terimakasih}

Penulis mengucapkan terimakasih kepada Ristekdikti yang telah memberikan kesempatan kepada peneliti dan memberikan pembiayaan penelitian pada Hibah Dosen Pemula.

\section{Daftar Pustaka}

1. Kalangi, Sonny J.R. Histofisiologi Kulit. Jurnal Biomedik. Unsrat. 2013

2. Armando R. Memproduksi Minyak Atsiri Berkualitas. Jakarta: Penebar Swadaya. 2009.

3. Umar, Muhammad I, Asmawi, M., Z., Sadikun,A. Atangwho, I.J., Yam, F. Y., Altaf, R. and Ahmed, A. 2012. Bioactivity-Guided Isolation of Ethyl-pmethoxycinnamate, an Anti-inflammatory from Kaempferia galangal L. Extracts. Molecules 2012, 17, 8720-87-8734. 
4. Aroonrerk N, Kamkaen N. Antiinflamatory Activity of Querous Infectoria Glycyrrhiza Uralensis, Kaempferia galanga L. and Coptis chinensis the Maincomponent of Thai Herbal Remedies for Aphthous Ulcer.Lagos, Nigeria: Journal of Health Res. 2009. Hal 17-22

5. Riasari, H., dkk. "Effectiveness of AntiInflammatory Plaster From Kencur (Kaempferia Galanga L.) Rhizome Ethanol Extract”. International Journal of Pharmaceutical Science and Research(IJPSR),2016.Vol.\&(4):17461749.

6. Patel, S., Shah, N., Nagesh, C., Venkatesh, J.S., dan Shankraiah, M. 2011. Formulation and Evaluation of Transdermal Patches of Losartan Potassium.Pharmacology online. Hal. 5057

7. Kumar V. Cotran RS, Robbins Sl.Buku Ajar Patologi. 7nd ed. Jakarta: Penerbit Buku Kedokteran EGC. 2010.

8. Pathan, I.B., dan Setty, C.M. "Chemical Penetration Enhancers For Transdermal Drug Delivery System", Trop. J. Pharm. Res. 2009. 8 (2): 173-179

9. Depkes RI, Direktorat Jenderal Pengawasan Obat dan Makanan, Direktorat Pengawasan Obat Tradisional. Parameter Standar Umum Ekstrak Tumbuhan Obat. Departemen Kesehatan Republik Indonesia. Jakarta. 2000. Hal. 17
10. DitjenPOM. Sediaan Galenik. Jakarta: Departemen Kesehatan RI. 1986. Hal. 10-11

11. Sangi, M.S., Momuat, L.I. dan Kumaunang, M., 2013. Uji toksisitas dan skrining fitokimia tepung gabah pelepah aren (Arange pinnata). Manado: Universitas Sam Ratulangi.

12. Farnsworth, N. R., Biological and Phytochemical Screening of Plants, J.Pharm. Sci., 1966. 55(3), 225-276.

13. Dewi, L. D. A. D. Y, Astuti, K. W., Warditiani, N.K. 2013. Penapisan Fitokimia Ekstrak Etanol 95\% Kulit Buah Manggis (Garcinia mangostana L.), Jurnal Farmasi Udaya.

14. Wardhani, Lilies Kusuma dan Nanik Sulistyani. 2012. Uji Aktivitas Antibakteri Ekstrak Etil Asetat Daun Binahong (Anredera scandens L. Moq.) terhadap Shigella flexneri Beserta Profil Kromatografi Lapis Tipis, Jurnal Imiah Kefarmasian, Vol. 2, No. 1, 2012: 1-16.

15. Depkes RI. Farmakope Herbal Indonesia.: Departemen Kesehatan Republik Indonesia. Edisi I. Jakarta 2008. Hal. 5458

16. Senja, R. Y., Issusilaningtyas, E., Nugroho, A. K., \& Setyowati, E. P. (2015). The comparison of extraction method and solvent variation on yield and antioxidant activity of Brassica oleracea 1 . Var. Capitata f. Rubra extract. Traditional Medicine Journal, 19(1), 43-48. 